\title{
Prerequisites for Addressing the Development of Soil Erosion in Sloping Lands of Azerbaijan
}

\author{
G Sh Mamedov and RAE ZH Aliyev* \\ Institute of Soil Science and Agro chemistry of ANAS, Azerbaijan
}

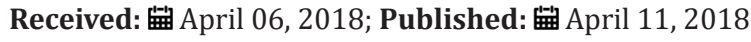

*Corresponding author: RAE ZH Aliyev, Institute of Soil Science and Agrochemistry of ANAS, Azerbaijan, Email: zaakirakademik@mail.ru

\begin{abstract}
The article examines the issues of the possibility of studying the areas of development by soil erosion and its control. The study proved that the development of soil erosion is based on the forming impact of natural and anthropogenic factors. The degree of potential danger and the possibility of prevention, taking into account the preservation of the environmental situation in the foothills of the Upper Shirvan in the example of the Shamakhi district of the Republic of Azerbaijan, were studied. The main tasks of the study were a determination of the amount and degree of development of eroded and erosion-prone soils of the foothill zones carried out on the basis of soil erosion surveys of the farms of the republic.
\end{abstract}

Keywords: Soil Erosion; assessment of the degree of erosion environmentally hazardous; Anti-erosion measures

\section{Review}

The territory of Azerbaijan is under environmental impacts the catchment of the Valley of the Caspian Sea. Here, environmental problems, which are the regional and depend on relations between States and for this reason, day after day they become strained. I must say that the soil exposed to erosion, forest plantations, mountain Grove, water sources, etc. natural education fail. In the geological and geographic region of the study has a rather complex structure, where the high mountains and steep slopes alternate Foothill areas and Plains, which in turn contributes to the development of a fairly Motley climate the diversity of vegetation.

The complexity of the geomorphological structure, the presence of steep slopes, as well as anthropogenic forcing has a significant value of intensity of runoff, which in turn reinforces the development of erosive processes, resulting in created wide ravines, which are presented in the final stage beams, changing appearance of geomorphological region in General. In the whole of Shirvan zone E M Shikhlinski [1] distinguishes 3 types of climate:

a. warm-temperate characteristic of lowland regions in area with relatively mild winters;

b. moderately warm moist type with a uniform distribution of rainfall throughout the year, covers part of the foothill zone and

c. cold climate with wet winters, characteristic of the foothills and mountain areas.

d. Minimum air temperature 0.50with falls in January, and the maximum in $23.60 \mathrm{c}$ in the month of July.

The average soil temperature ranges from -10p-30.70c. Minimum temperature of soil in -10with falls on January, maximum 30.00c (July) and August 30.70months. Annual rainfall is $692 \mathrm{~mm}$, most of which falls in the months of April to June. The annual value of evaporation $825 \mathrm{~mm}$, the average relative air humidity is $71 \%$ fluctuate time of year from 59 to $87 \%$ [1]. It should be recognized that the results of the many fundamental and applied research on the development of soil erosion and erosion events proved that modern methods of study inevitably and naturally it was practiced always, however, it must be said that using new works mentioned themed, opens the next stage information experimental and applied research in the field of science, where the mingled with a test ways of dealing on prevent it by an integrated approach solutions challenge studies on development of erosion of natural habitats. It is known that is not a complete list of information on soil erosion and responses at different administrative levels overlook 
the content beyond the Visual and other accounting materials researchers and university textbooks and may have substantial assistance to authors on many scientific and applied issues that could not be addressed fully in the Republic so far.

Direction of study on soil erosion, their mapping and designing erosion-preventive, recommended for students is wide and diverse, and may be offered basic blocks (lines): soil erosion researchterminology, classification; the criteria used to determine the risk of erosion; assessment and mapping of erosion dangerous lands; mapping of eroded soils; protection of soil from erosion; designing erosion control activities; environmental, social and economic effectiveness of erosion control measures; status of research on the issue of protecting the soil from erosion in Azerbaijan and other countries of the world. The natural and climatic conditions of the Republic due to the water balance deficit contributes to development and erosion, deflation, and that require specific, progressive methods of development here soil, crops, land reclamation and protection without having small the Land Fund. It should be noted that in the Republic basic arrays suitable for irrigated agricultural land use is already a component of 1.410 million ha have been mastered and further expansion of arable land is only possible due to the development of less productive land that and requires excessive protection from soil erosion on the reclaimed lands, maintaining and enhancing soil fertility is of great importance for the country.

In the process of realization of scientific research conducted by the authors in the Institute Erosion and Irrigation, NANA on the direction of research in their monographs soil erosion is represented as a function of the natural and anthropogenic factors and its environmental consequence. The authors assumed that each science requires some precision and clarity of concepts and achievements of new results continuously improved control measures and classification of objects. These issues have engaged many scholars, so for example: A.N. Zavarickij (1947); Sobolev, S.S. (1948), K.A. Alekperov D.A. (1950-1970), Khalilov M.h. (19721989)), A.A. Ibrahimov (1967-2010), Shvebs G. (1977), Belgibaev M.E. (1970), Budagov B.A. (1953-2006), Aliyev, B.H. (19902016);M.N/ Zaslavsky (1972-1979), etc.), in the writings of which

Table 1: Land distribution in natural and economic areas of the Republic on relief conditions.

\begin{tabular}{|c|c|c|c|c|c|}
\hline \multirow{2}{*}{ Natural-economic zones } & Suitable for Orosz. Earth pouslovijam & \multicolumn{3}{|c|}{ Including slopes } \\
\cline { 3 - 6 } & relefa & $<\mathbf{0 . 0 5}$ & $\mathbf{0 . 0 5}+\mathbf{0 . 1 0}$ & $\mathbf{+ 0 . 2 0 ~ 0 . 1 0}$ & $\mathbf{+ 0 . 4 0 ~ 0 . 2 0}$ \\
\hline 1 & 2 & 3 & 4 & 5 & 6 \\
\hline Ganja-Kazakh & 427.50 & 251.0 & 72.8 & 63.70 & 40.00 \\
\hline Shirvan & 680.80 & 522.6 & 50.0 & 66.10 & 42.10 \\
\hline Karabakh-Milskaja & 749.00 & 567.6 & 80.20 & 47.40 & 53.80 \\
\hline Waterless Mugano-Saljanskaja & 429.8 & 402.4 & 2.8 & 17.1 & 7.5 \\
\hline Shaki-Zakatalskaja & 322.7 & 236.5 & 42.7 & 23.8 & 19.7 \\
\hline Lankaran & 81.5 & 79.5 & 2.0 & - & - \\
\hline Absheron & 52.7 & 31.1 & 21.6 & - & - \\
\hline
\end{tabular}

Citation: G Sh Mamedov, RAE ZH Aliyev. Prerequisites for Addressing the Development of Soil Erosion in Sloping Lands of Azerbaijan. Arc Org Inorg Chem Sci 2(4)- 2018. AOICS. MS.ID.000143. DOI: 10.32474/AOICS.2018.02.000143. 


\begin{tabular}{|c|c|c|c|c|c|}
\hline Cuba-Xacmaz & 203.5 & 179.1 & 24.4 & - & - \\
\hline Upper Garabag & 133.7 & 24.7 & 27.8 & 37.6 & 43.4 \\
\hline Nakhchivan & 154.2 & 95.3 & 38.0 & 11.2 & 9.7 \\
\hline Total Republic & 3235.4 & 2390.0 & 362.3 & 266.9 & 216.2 \\
\hline
\end{tabular}

To conclude on the slopes of 15-200 place gardens and vineyards. Often sklonovye lands in 30-400 degrees or greater, are used for vineyards with the direction of the rows along the slope, posing a dire conditions for exploitation of agricultural machines and enhanced flushing topsoil in the aisles. Therefore, the author considers when laying new vineyards and orchards should not go on seemingly a more economical way of bookmarks in the direction of the slope. There is also use of steep slopes under crops grain and forage crops. [2,4]. Ploughing and tillage on such areas run along the slope, which contributes to the flushing of soil and a sharp decline

Table 2: Exposure to soil erosion in mountain areas of Azerbaijan.

\begin{tabular}{|c|c|c|c|c|c|}
\hline \multirow{2}{*}{ Areas } & \multirow{2}{*}{ Total area in th. HA } & \multicolumn{3}{|c|}{ Including exposure to erosion } \\
\cline { 3 - 6 } & & not podverzhths HA, $\%$ & Little & medium & strongly \\
\hline Dashkesan & 90.3 & $23.3 / 25.8$ & $18.3 / 20.3$ & $25.6 / 28.3$ & $23.1 / 25.6$ \\
\hline Gədəbəy & 150.3 & $73.6 / 49.0$ & $20.1 / 13.4$ & $29.8 / 29.8$ & $26.8 / 27.8$ \\
\hline Lachin & 124.3 & $48.4 / 38.9$ & $27.2 / 21.9$ & $18.9 / 15.2$ & $29.8 / 24.0$ \\
\hline Lachin & 166.5 & $56.7 / 34.1$ & $26.3 / 15.8$ & $36.7 / 22.0$ & $46.8 / 28.1$ \\
\hline Kubadly & 79.8 & $25.7 / 33.5$ & $6.9 / 8.6$ & $28.7 / 36.0$ & $17.5 / 21.9$ \\
\hline Zangilan & 72.5 & $24.6 / 33.9$ & $16.4 / 22.6$ & $14.6 / 20.2$ & $16.9 / 23.3$ \\
\hline Lerik & 136.5 & $43.6 / 32.2$ & $19.4 / 14.3$ & $27.8 / 20.5$ & $44.7 / 33.0$ \\
\hline Yardimli & 12.5 & $25.1 / 34.6$ & $12.6 / 17.4$ & $10.6 / 14.6$ & $24.2 / 34.4$ \\
\hline Mountain part Goranboja & $57.6 / 20.8 / 19.5$ & $7.7 / 36.1$ & 33.9 & 13.4 & $9.6 / 16.6$ \\
\hline Julfa & 99.4 & $9.9 / 10.0$ & $16.3 / 16.4$ & $25.3 / 25.5$ & $47.9 / 48.1$ \\
\hline Shahbuz & 81.4 & $61.1 / 19.8$ & $5.4 / 6.6$ & $15.7 / 19.3$ & $14.2 / 54.3$ \\
\hline Ordubad & 92.4 & $7.0 / 7.6$ & $9.5 / 10.6$ & $13.5 / 14.6$ & $62.1 / 67.2$ \\
\hline Absheron & 535 & $57.5 / 10.7$ & $116.8 / 21.8$ & $165.5 / 30.9$ & $195.5 / 36.6$ \\
\hline
\end{tabular}

Environmental pollution has become one of the most important Wednesday challenges, special role where belongs to the heavy metals that have the ability to accumulate in soils and through them get into foods while promoting and soil degradation. Zoning of the territory of the Republic on irrigation technique and degree of soil erosion in republics showed that 14 districts have a tense situation, in which there is a risk the withdrawal of arable land here due to the intensive use of in view of the complete degradation of soils. In Azerbaijan are found all types of erosion (incl. water, mudflow, wind, surface, line, etc.) the susceptibility of soil erosion in mountain areas of Azerbaijan are listed in the table (Table 2) As can be seen from the table, the most common is water erosion, which develops in mountain regions more intensively. Mountain soil in this and other exposed to erosion, which covers $51.0-92.4 \%$ land area. The Shaxbuz, and Also areas of soil subjected to strong erosion and, respectively, accounted for 54.3 and 67.2\%. [2] You can enlarge irrigated lands up to 1235 ha in its fertility. Long-term systematic not a legitimate use of chemical plant protection products in the region, as the years of Soviet power, and now especially pesticides, is one of the main problems in the agricultural zone of the Republic as Lip-Hachmasskoj, GanjaGazakh, Upper shirvani and Holding. Pollution of the soil here has a negative impact on plants; reduce the harvest of crops and the potential loss 1 soil fertility. Along with the pollution of ecosystems affected by the negative consequences for people and livestock in the region.
The above mentioned mountainous areas, thanks to the collection of mud water in small ponds, over 1300 hectares of wet or not exposed farming soils hold watering, which serves to protect the mudflow and irrigation erosion in these areas. Furthermore, by reducing soil erosion, introduction of a number of events, w. h. ensure the soil in sufficient quantities of mineral fertilizers in these areas can be achieved production of 35.0 thousand tons of wheat, 12.0 thousand tons of tobacco, 10-15 thousand tons of vegetables, 95-100 thousand tons of potato, as well as through improved forage base significantly improve livestock production. [1,2,5] On the mountain and Foothill regions on sloping lands of Azerbaijan using newly developed technological means of irrigation, us has been implemented large amount of long-term research work under the supervision of B.H. Aliyev [2].

Given the above, it is recommended for mountain and Foothill areas following irrigation methods: 
i. furrows with a slit;

ii. Sprinkling with low intensity of rain;

iii. finely dispersed moistening in combination and without combination with sprinkling;

iv. Drip irrigation, etc.

Watering on furrows with a slit of terrain $<0,03$ for other crops under the conditions under consideration, the surface watering method is not recommended because of uneconomical water consumption. It should be noted that the creation and development of new progressive irrigation methods is an exception to irrigation erosion, saving irrigation water and not violating environmental protection of the environment. From the foregoing it follows that when developing mountain slopes not only in Azerbaijan but also in the countries of the world, a cautious approach is required to properly select the technique and technology of irrigation is recommended for irrigation of tilled crops on lands with slopes. In conclusion, on slopes 15-200 it is necessary to place gardens and vineyards. Often, slopes of 30-400 and more degrees, are used for vineyards with the direction of rows along the slope, which creates the most difficult conditions for the operation of agricultural machines and enhanced flushing of the upper fertile soil layer in the inter-row spacing. Therefore, the author believes when laying new gardens and vineyards, one should not go on an apparently more economical way of laying in the direction of the slope. There is also the use of steep slopes for the sowing of grain and forage crops $[6,7]$.

To solve this problem, it is necessary to differentiate the lands according to their natural potential and the degree of erosion, with the subsequent definition of a set of measures for cessation of the processes of degradation and restoration of soil fertility with subsequent zoning of the territory of the republic according to the degree of erosion with mandatory consideration of all factors affecting the condition and use of land in different types of soil in the republic. It must be recognized, however, that the effectiveness of our measures of erosion control and the prevention of erosion risk are complex defenses, promotes regulation of runoff, soil protection from flushing, erosion, however, the restoration and improvement of soil eroded and the involvement of eroded land in the rational use of the agriculture Republic $[8,9]$.

\section{References}

1. Mamedov RG (1970) Agrofizicheskaja characteristics of soil priaraksinskoj stripes with 321.

2. Aliyev GA (1978) Soils of the big Caucasus within the Azerbaijan SSR, Baku Elm p.15.

3. Mamedov GSh (2000) land reform in Azerbaijan: legal, scientific and environmental issues pp.371.

4. Vernadsky VI (1908) works on the General history of Science [text], Nauka.

5. Shyhlinskij EM (1968) climate in Azerbaijan, Baku, with 341, Asia.

6. Aliyev BH, Aliyev G (2000) Aliyev and erosion Problems in Azerbaijan and ways of its solution. Izd-vo Zia-CPI "Nurlan", Asia.

7. Babayev MP, AM Jafarov (2017) modern soil cover of the Greater Caucasus, Baku pp. 344.

8. (2007) Biodiversity and climate diversity. AGI, UNEP, Kenya.

9. VE Flint (2002) conservation and restoration of biodiversity. Scientific and educational-methodical Center pp. 282.
This work is licensed under Creative Commons Attribution 4.0 License

To Submit Your Article Click Here:

Submit Article

DOI: 10.32474/AOICS.2018.02.000143

\section{AOICS}

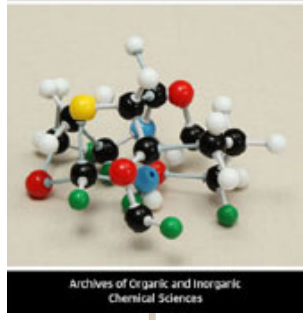

Archives of Organic and Inorganic Chemical Sciences

\section{Assets of Publishing with us}

- Global archiving of articles

- Immediate, unrestricted online access

- Rigorous Peer Review Process

- Authors Retain Copyrights

- Unique DOI for all articles 